\title{
CATAIJOGUE OF A COLLECTION OF BIRDS MADE ON THE ISLAND OF COZUMEL, YUCATAN, BY THE NATURALISTS OF THE U. S. FISH COMMISSION STEAMER ALBATROSS, CAPT. Z. L. TANNER, COMMANDER.
}

\section{RY ROEBET ETITEWA.}

In a pamphlet* of four pages, entitled "Description of some New Spe. cies of Birds from Cozumel Island, Yucatan," published at Washington, February 26, 1885, the writer gave brief diagnoses of thirteen new spe. cies, and promised " a full report upon the collection" to " be published in the Proceedings of the U. S. National Museum." On account of pressure of other duties, it has not been found practicable to make the report as complete as might be desired, or to present it sooner; but it is believed that on many accounts it will be better to publish it in its present form, rather than secure greater elaboration at the expense of additional delay.

The collection upon which this paper is based comprises 232 skins and 177 specimens in alcohol, the total number of specimens being 429 and of species 57. It was made during the period dating from January 22-29, 1885, by Mr. J. E. Benedict, resident naturalist of the AIbatross, assisted by Mr. Thomas Lee, Dr. Tarleton H. Bean, and Capt. J. W. Collins.

Before proceeding further with this paper I would refer to one by Mr. Osbert Salvin $\dagger$ in the Ibis, for A pril, 1885 (pp. 185-195, pl. v), in which is given a brief description of the island, and an annotated list of 27

* This paper will also be found in Vol. III (1884-'85) of the Proceedings of the Biological Society of Washington. The original edition comprised 250 copies, many of which were distributed on the date of printing, and others on March 2. The gratuitous distribution of this pamphlet by the author does not deprive it of its publie eharacter, it having thus acquired a circulation far more extensive than if offered for sale; and this is especially true since it was sent immediately or very soon after printing to all who were supposed to be specially interested in the subject to which it pertained. Both the Proceedings of the Biological Society of Washington and those of the U. S. National Museum are published uuder the immediate auspices of the Smithsonian Institution, and the edition of separately dated signatures or extras is specially designed to secure "immediate or extensive circulation," as recommended by the committee of the British Association. The number of pages comprised in a publication is a matter of even less importance, it seems to us, than the date of printing (in contradistinction to date of publication); and it will hardly be questioned that if the paper under consideration had comprised a hundred or more pages its claim to recognition would not have been challenged. In short, having all the requirements of a separate publication, including an edition equal to that of many important ornitbological works, and having been promptly and extensively distributed, there appears to be no reason why the paper which has called forth these remarks may not be legitimately recognized and quoted. (Cf. The Ibis, July, 1885, pp. ‘37-238.)

t On a Collection of Birds from the Island of Cozumel, by Osbert Salvin, M. A., F. R. S., \&c. > The Ibis, ser. v, vol. III, April, 1885, pp. 185-195, pl. v. 


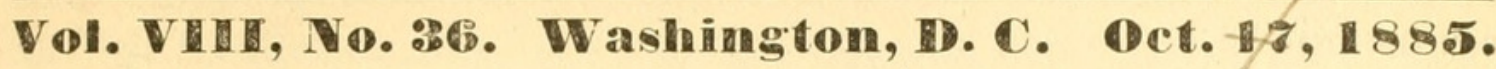

species, based on a small collection made by Mr. E. C. J. Devis. In this paper are mentioned 6 species which were not obtained by the naturalists of the Albatross, viz, Cyanospiza (=Passerina) ciris, Dolichonyx oryzivorus, Hadrostomus (undetermined species), Picus scalaris, Columba leucocephala, and Engyptila jamaicensis. Two supposed new species were also described and one of them figured, these being Harporhynchus melanostoma and Spindalis exsul (pl. v), equal, respectively, to our H. guttatus and S. benedicti. In order to render the list of Cozumel birds more complete, it has been thought best to incorporate the additioual species given by Mr. Salvin, but at the same time distinguishing them typographically from the others.

\section{Family SYLVIID E.}

Subfamily PoLIOPTILINAE.

1. Polioptila cœrulea (Linn.). Eight specimens.

\section{Family MIMID $\mathbb{E}$.}

2. Harporhynchus guttatus, Ridgw.

Harporhynchus guttatus, Ridgw. Descr. New Sp. B. Cozumol, February 26, $1885,1$.

Harporhynchus melanostoma, SALV. Ibis, April, 1885, 187.

SP. CHAR.-Similar to $H$. longirostris (Lafr.), but smaller, darker, the bill wholly deep black, and all the markings more sharply defined.

Adult ô (No. 102,454, U. S. Nat. Mus., Cozumel, January 23, 1885): Above deep ferruginous-umber, darker or inclining to burnt umber on the tail; middle and greater wing-coverts sharply tipped with buffy white (nearly pure white on middle coverts), the white tips preceded by a broader subterminal bar of blackish. Lower parts buffy white, the entire chin, throat, abdomen, anal region, and crissum immaculate, the latter, also the flanks, more decidedly buff ; jugulum, breast, sides, and flanks marked with guttate streaks or spots of dull black, similar but smaller markings bordering the throat on each side almost to the chin. Side of head uniform brown, paler than pileum, and bordered below by a dull-white malar stripe. Bill uniform deep black; legs and feet dusky horn-color. Wing, 3.55 ; tail, 4.45 , graduated for 1.00 inch ; culmen, 1.25 ; bill from nostril, .85; tarsus, 125 ; middle toe, .80 .

The two other specimens in the collection are undetermined as to sex. No. 102,456 agrees essentially with the type as described above, but differs in its measurements, and is perhaps a female. The other (No. $102,455)$ is almost pure white beneath, there being a barely perceptible

Proc. Nat. Mus. $8 \check{-}-36$ 
baffy tinge on the jugulum. The measurements of these two examples. are as follows:

\begin{tabular}{|c|c|c|c|c|c|c|c|c|}
\hline Number. & Date. & Wing. & Tail. & Culmen. & $\begin{array}{l}\text { Bill from } \\
\text { nostril. }\end{array}$ & Tarsus. & $\begin{array}{c}\text { Middle } \\
\text { toe. }\end{array}$ & $\begin{array}{l}\text { Graduation } \\
\text { of tail. }\end{array}$ \\
\hline $\begin{array}{l}\text { No. } 102,455 . \\
\text { No. } 102,456 .\end{array}$ & $\begin{array}{l}\text { Jan. } 28 \\
\text { Jan. } 29\end{array}$ & $\begin{array}{l}3.40 \\
3.40\end{array}$ & $\begin{array}{l}4.10 \\
4.10\end{array}$ & $\begin{array}{l}1.25 \\
1.20\end{array}$ & $\begin{array}{l}.85 \\
.80\end{array}$ & $\begin{array}{l}1.25 \\
1.15\end{array}$ & $\begin{array}{l}.85 \\
.85\end{array}$ & $\begin{array}{l}.90 \\
.90\end{array}$ \\
\hline
\end{tabular}

The occurrence of a species of this genus on Cozumel is remarkable, since no Harporhynchus has yet been detected in Yucatan, H. longirostris, its nearest ally, having its southern limit, so far as known, in the State of Vera Cruz (Jalapa, Cordova, and Mirador).*

\section{Mimus gilvus gracilis (Caban.).}

Seven examples, agreeing with Yucatan (Merida) specimens, except that the gray of the upper parts is decidedly purer or less brownish, as is also the white of the lower parts. They all agree with the Yucatan specimens in having the wings decidedly black, in strong contrast with the rather light ash gray of the upper parts, and relieved by very sharply defined pure white tips to the wing-coverts (both rows), being thus very readily distinguished from M.gilvus and allied forms. (See these Proceedings, Vol.5, pp. 10-12.) Some of the Cozumel specimens have the superciliary stripe very distinct, being in this respect similar to $M$. gilvus, from which, however, they may be distinguished not only by the very different coloration of the wings, but also by the greater extent of white on the tail feathers, that on the lateral pair of rectrices approaching very closely to the end of the under tail-coverts.

\section{Galeoscoptes carolinensis (Liun.).}

Three specimens. Said to be common, associated with Melanoptila glabrirostris, and supposed by the natives to be the female of that species!

\section{Melanoptila glabrirostris, Sel.}

Twelve specimens (seven in alcohol), apparently the same as the true M. glabrirostris; but of the latter we have only one imperfect skin for comparison, the bill and feet being broken and the plumage perhaps not of the brightest. The five Cozumel skins are a rich, silky violet-black, except the wings and tail, which are greenish black, and the abdomen, which is a dead black, or almost without gloss. The violet color of the back extends to the upper tail-coverts, which are only a little more blu-

* Mr. Salvin thus refers to this curious isolation of $H$. gullatus, and its close relationship to H. longirostris: "This Harporhynchus is allied to H. longirostris (cf. Salv. \& Godm. Biol. Centr.-Am., Aves, i. p. 31), and at first sight might easily be mistaken for it. The mandible is black to the base, and the dimensions, especially the wing, are much less. Moreover, there is a wide gap in the ranges of the two birds, H. longirostris, so far as we know at present, not occurring in any locality nearer than the State of Vera Cruz." (Ibis, April, 1885, p. 187.) 
ish. In the specimen of true glabrirostris (No. 30,652, Half Moon Bay, British Honduras, May 10, 1862) the plumage is less glossy, especially on the rump and upper tail-coverts, while the bill and feet, as nearly as can be told from their mutilated condition, appear to be weaker. The differences are at most very slight, however, and unless perfectly constant would not suffice for the separation of the Cozumel bird even as a local race.

Very abundant, and said to be a very brilliant and melodious song. ster.

\section{Family TROGLODYTID㕕.}

\section{Troglodytes beani, Ridgw.}

Troglodytes beani, RiDGw. Deser. New Sp. B. Cozumel, February 26, 1885, 1.

SP. CHAR. - Largest species of the genus (wing, 2.10-2.20; culmen, .75 or more). Above grayish brown, becoming more of a burnt-umber tint posteriorly, the tail and wings rather distinctly barred with dusky, the other upper parts either perfectly plain or with barely discernible narrow bars of a darker tint on lower back, etc. Lower parts white, the jugulum and sides tinged with brown, the flanks decidedly brownish; lower tail-coverts light rusty, tipped with white and barred with dusky.

Adult o (type, No. 102,473, U. S. Nat. Mus., Cozumel, January 28, 188.) : Above plain brown, more grayish anteriorly, and more of a burntumber cast posteriorly, especially on the rump, where the feathers have concealed, subterminal, large guttate spots of white, the basal portion being slate-colored. Tail and wings duller umber than rump, narrowly and indistinctly barred with dusky. Lower parts white, purest on the malar region, chin, throat, and abdomen, the sides and flanks pale fulvous-brown, the lower tail-coverts light rusty, tipped with white and barred with blackish. Maxilla black, the tomium paler; mandible with terminal half dusky, the basal half light yellow; legs and feet horn color. Fifth and sixth quills longest; tail graduated for .30 of an inch. Wing, 2.20 ; tail, 1.90 ; culmen, .81; bill from nostril, .50; tarsus, .80 ; middle toe, .50 .

Four of the five specimens have no indication of bars on the lower back, rump, or upper tail-coverts; the fifth, however (No. 102,474, $\delta$ ad.), has very indistinct and narrow darker bars on all these portions.

The only species which this one resembles in coloration is the $T$. inquietus, Baird, from Panama, which, however, is much smaller, and aiffers in other characters.

\section{Family MNIOTILTID $\mathbb{E}$.}

7. Mniotilta varia (Linn.). Three specimens.

8. Compsothlypis americana (Linn.). Seven specimens.

9. Dendroica petechia rufivertex, Ridgw.

Dendroica petechia rufivertex, RIDGw. Descr. New Sp. B. Cozumel, February 26, 1885, 1; Proc. U. S. Nat. Mus., VIII, 1885, 348 (detailed description and comparison with allied forms.) 
10. Dendroica virens (Gmel.). Fifteen specimens.

+11. Dendroica cœrulescens (Linn.). Adult male and femali:

+ 12 Dendroica maculosa (Gmel.). Two examples.

13. Dendroica dominica albilora Baird.

Seven specimens, all decidedly referable to this form, since, although three examples have more or less yellow above the lores, the measurements are those of albilora. Respecting the characters of this form, it may be remarked that while as a rule the superciliary stripe is entirely white, it is often yellow anteriorly in specimens which are otherwise typical. In true dominica, on the other hand, the superciliary stripe is apparently always yellow anteriorly, while the bill is much longer than in the western form.

The occurrence of this form to the exclusion of the true dominica, which alone winters in the West Indies, shows the importance of carefully discriminating between geographical races, however slightly they may be differentiated. The following species is a similar illustration of the case, although the facts of distribution are different, the typical form wintering in both the West Indies and on Cozumel (but not on the mainland), while D. palmarum hypochrysea apparently does not pass beyond the Sonth Atlantic and Gulf States.

-14. Dendroica palmarum (Gmel.). Seven specimens.

+15. Dendroica discolor (Vieill.). Three specimens.

This is another species of Eastern North America which winters both in the West Iudies and on Cozumel, but apparently not on the mainLand of Middle America.

+ 16. Seiurus noveboracensis notabilis, Ridgw. Two specimens.

+17. Seiurus aurocapillus (Linn.). Two specimens.

+13. Geothly pis trichas occidentalis, Brewst. Three specimens.

These are interesting as showing that it is the interior and western form which winters on Cozumel, and not the eastern. The latter winters in the South Atlantic States, the Bahamas, Cuba, and Jamaica.

+ 19. Sylvania mitrata (Gmel.). Four adult males.

†20. Setophaga ruticilla (Linn.). Seventeen specimens.

\section{Family COEREBID E.}

+21. Certhiola caboti, Baird.

Twenty-four skins and twenty-two alcoholic specimens confirm the validity of this species. It is, as indicated by Professor Baird in the original description (American Naturalist, VII, 612, and Hist. N. Am. B., I, 1. 427), nearly kelated to C. bahamensis ; but it has a still closer ally in the recently described C. tricolor, nobis, from the island of Old Providence, in the Caribbean Sea. (See these Proceedings, Vol. VII, p. 178.) With the latter it agrees in the greater extension of the yellow of the lower parts and the darker color of the back than in C. bahamensis. 


\section{Family VIREONID $\nexists$.}

22. Vireo cinereus, Ridgw.

Vireosylvia cinerea, RIDGw. Descr. New Sp. B. Cozumel, February 26, $1885,2$.

Vireo magister, SALVIN, Ibis, April, 1885, 188 (nee BAIRD).

SP. CHAR.-Agreeing with V. magister, BAIRD, in absence of dusky submalar streak and dusky streak on side of crown, but plumage deeidedly ashy, instead of brownish olive. (No spurious primary.)

Adult (type, No. 102, 656, U. S. Nat. Mus., Cozumel I., Yucatan, January $29,18 x 5)$. Above dull ash-gray, the pileum concolor with the dorsal region, but the lower part of rump and upper tail-coverts, with edges of rectrices and primaries, decidedly tinged with light olive-green. No trace of dusky streak on sides of pileum. A distinct and rather broad superciliary stripe of dull buffy white, becoming more ashy above the auriculars. A dusky grayish lorai stripe, and a similar but less distinct postocular streak. Auriculars light brownish gray, gradually fading to dull whitish beneath the eye and on the throat. Lower parts dull white, very faintly tinged with buff, the sides and flanks rather abruptly olive gray. Liniug of wing and crissum yellowish white. No spurious primary. Bill dusky, the basal half of mandible whitish (pale bluish. in life?); legs and feet plumbeous-dusky (plumbeous-blue in life?)。 Wing, 3.00 ; tail, 2.30 ; culmen, .90; bill from nostril, .45; tarsus, .80; middle toe, .45 .

This species is closely related only to V. magister, Baird. In coloration, however, it bears a close general resemblance to V.gilvus, more so in iact than to any other member of the genus.

Two specimens in the collection.

+23. Vireo flavifrons, Vieill. One specimen.

-24. Vireo noveboracensis (Gmel.). Four specimens.

25. Vireo bairdi, Ridgw.

Vireo bairdi, RiDGw. Deser. New Sp. B. Cozumel, February 26, 1885, 2.

SP. CHAR.-Above tawny olive, the wings with two broad yellowish white bands. Lores and median lower parts pure white; lateral lower parts, from cheeks to flanks, deep tawny buff, in abrupt contrast with. the white.

Adult ô (No. 102,635, U. S. Nat. Mus., Cozumel I., Yucatan, January 25, 1885). Above deep olive-brown, or tawny olivaceous, the pileum more grayish, although decidedly tawny anteriorly and laterally; remiges and rectrices edged with yellowish olive-green, the tertials with broader edgings of yellowish white; middle and greater wing-coverts edged with olive-greenish, and broadly tipped with yellowish white. Lores, orbital ring (interrupted on upper eyelid), malar region, chin, throat, and median lower parts pure white. Lateral lower parts, ineluding sides of forehead, auriculars, sides of neck and breast, sides, and flanks, deep tawny buff or cinnamon-ochre, in abrupt contrast with 
the white. Lining of wing pure white, the edge of wing and axillars tinged with sulphur-yellow ; crissum white, faintly tinged with yellow. Maxilla light brown, with paler tomium; mandible whitish; legs and feet grayish brown (plumbeous in life ?). Wing, 2.50 ; tail, 2.15 ; culmen, .60; bill from nostril, .30; tarsus, .89; midille toe, .45 .

This species is so very distinct as not to require comparison with any other at present known, being: wholly unique in and immediately recognizable by, the pure white median lower parts, strongly and abruptly contrasted with the bright tawny or ochreous lateral portions. It belongs decidedly to typical Vireo, and not to the section Vireonella, as defined by Professor Baird in his "Review of American Birds" (p. 326).

The species is dedicated to Prof. Spencer F. Baird, among whose numerous valuable contributions to ornithological literature is an elaborate monograph, by far the best and most complete extant, of the North and Central American Vireonida, in the work above mentioned (pages $322-400)$.

Six skins and thirteen alcoholic specimens are represented in the collection.

+26. Cyclorhis insularis, Ridgw.

Cyclorhis insularis, RIDGw. Deser. New Sp. B. Cozumel, February 26, 1885, 2.

SP. CHAR.-Similar to C. flaviventris in color of pileum, but agreeing with $C$. ochrocephala in coloration of the lower parts.

Adult (type, No. 102,659, Cozumel I., Yucatan, January 28, 1885) : Pileum dull brownish gray, bordered anteriorly and laterally by a welldefined frontal band and superciliary stripe of bright rufous; malar region, auriculars, and nape, cinereous, the chin similar but paler. Remaining upper parts uniform olive-green, decidedly duller, or less green, than in C. flaviventris or C.ochrocephala. Throat, jugulum, side of breast, sides, and flanks, light olive-yellow ; breast, abdomen, anal region, and erissum, white; lining of wing pale sulphur-yellow, much paler than in the allied species. Maxilla and terminal portion of mandible pale brown; basal half of mandible dusky (plumbeous or bluish in life?); legs and feet light brown (fleshy in life ?). Wing, 3.30 ; tail, 2.60 ; culmen, .\$5; bill from nostril, .50; depth, .38; tarsus, 1.00 ; middle toe, .55.

Another specimen (No. 102,658, January 25), also a female, but evidently a younger bird, is decidedly duller in color, the pileum being more brownish, the rufous frontal band and superciliary stripe paler and less sharply defined, and the white of the abdominal region much more restricted, being apparently confined to the central and lower portion of the abdomen itself. This last feature, however, is to a great extent owing to the "make" of the skin, which is considerably contracted, but perhaps depends more on immaturity of the specimen. Wing, 3.00; tail, 2.30 .

It is a singular fact that the only other species of the genus, besides C. flaviventris, Lafr., which this resembles, is the far separated C. ochro- 
cephala, Tschudi, of southeastern Brazil, with which $C$. insularis agrees very closely in the coloration of the under parts. Indeed, it is at first difficult to determine whether $C$. ochrocephala or $C$. flaviventris is its nearest ally ; but geographical considerations, together with a more exact resemblance to C. flaviventris in the coloration of the upper parts, leads us to regard the latter as most closely related.

\section{Family TANAGRID无.}

27. Spindalis benedicti Ridgw.

Spindalis benedicti, RIDGw. Descr. New Sp. B. Cozumel, February 26, 1885, 2. Spindalis exsul, Salvin, Ibis, April, 1885, 189, pl. v.

SP. CHAR.-Adult ô (t trpe, No. 102,675, U. S. Nat. Mus., Cozumel I., Yucatan, January 29, 1885) : Entire pileum, lores, suborbital region, auriculars, and broad submalar stripe, deep black; broad superciliary stripe and still broader malar stripe pure white, the latter wider posteriorly, and extending backward beyond the auriculars; chin white, stripe down middle of throat rich yellow. Nape and jugulum dark chestnut-brown. Back and scapulars dark olive-brown; upper part of rump yellowish olive, lower part, with upper tail-coverts, rich dark chestnut. Lesser wing-coverts rich chestnut, the anterior and innermost feathers black; rest of wings, with tail, deep black, the greater coverts and tertials broadly edged with pure white; a white patch at base of primaries, concealed by the coverts, however, on the two outer quills; primaries and secondaries narrowly edged with white, on the latter, however, extending only about two-thirds of the way to the tips of the greater coverts. Two outer rectrices with the terminal half mainly white; intermediæ with inner webs broadly edged with white. Breast and upper part of abdomen rich yellow ; lining of wing, sides of abdomen, anal region, and crissum, white ; sides and flanks light grayish. Bill blackish, the mandible plumbeous basally; feet dusky (plumbeous or bluish in life?). Wing, 3.40 ; tail, 2.90 ; culmen, .60; bill from nostril, .35 ; tarsus, .85 ; middle toe, .62 .

Adult \& (No. 102,673, U. S. Nat. Mus., Cozumel I., Yueatan, January 28, 1885): Above uniform grayish olive; wings externally similar, but darker, the greater coverts and tertials showing broad but not sharply defined paler edges; primaries dusky, narrowly edged with grayish white, and showing a small white speculum at base of fourth and fifth quills; primary-coverts and alulæ plain dusky. Tail without white spots. Auriculars streaked with dusky and pale grayish olive; chin and broad malar stripe (poorly defined) pale grayish, tinged with olive; rest of lower parts pale grayish olive, changing to yellowish white on the belly, and soiled whitish on crissum and lining of wing. Wing, 3.20 ; tail, 2.70

Sixteen skins (eleven $\hat{\delta}$, five $q$ ) and ten alcoholic specimens are included in the collection. 
This fine species, perhaps the handsomest of the genus, agrees best in coloration with S. zena (Linn.), in the restriction of the yellow on the lower parts, and in the chestnut nape and upper tail-coverts. S. zena, however, is much smaller (wing 3.15 and tail 2.70 in the $\delta$ ), with the bill altogether more slender, has the back, scapulars, and lesser wingcoverts intense black, and much less of chestnut on the jugulum, which is widely separated from the yellow throat-stripe. In size it comes nearest the Jamaican species (S. nigricephala, James.), but the coloration is widely distinct.

+ 28. Piranga roseigularis Cabot.

Three adult males, apparently identical with Yucatan specimens, although they have not been directly compared.

\section{Family FRINGILLID $A$.}

\section{+29. Coturniculus savannarum passerinus (Wils.).}

Two specimens, belonging decidedly to the eastern form, and not the western perpallidus.

30. Passerina cyanea (Linn.).

One example, an immature male.

[31. Passerina ciris (Linn.). Devis collection.]

+ 32. Euetheia olivacea intermedia Ridgw.

Euetheia olivacea intermedia, RIDGw. Descr. Nęw Sp. B. Cozumel, February $26,1885,2$.

SUBSP. CHAR.-Intermediate between and connecting E. olivacea (Gmel.) and E. olivacea pusilla ( $\mathrm{Sw}$.), having the grayer cheeks of the former and greater extension of black on the breast of the latter. Type, No. 102,710, ơ ad., Cozumel, January 28, 1885.

This interesting series, consisting of nineteen specimens (six skins, the remainder alcoholic), completely connects the West Indian E. olivacea with the continental E. pusilla. It being impossible to refer them to either, however, without doing injustice to the claims of the other, and their habitat being moreover isolated, we have felt obliged to name the Cozumel bird as a local race, as the best way out of the difficulty.

33. Cardinalis cardinalis saturatus Ridgw.

Cardinalis saturatus, Ridgw. Deser. New Sp. B. Cozumel, February 26, 1885, 4.

SUBSP. CHAR.-Similar to C. cardinalis coccineus, but coloration still more intense, and the bill shorter and relatively much thicker.

Adult ô (type, No. 102,720, Cozumel, January 24): Capistrum, including whole upper part of throat, black, this meeting very narrowly across the forehead. Rest of head and neck, with entire lower parts, deep vermilion-red, purer and more intense on the lower parts, somewhat obscured by dark brownish red tips to the feathers of crest, ete. Upper parts, including nape, uniform dark claret-red, without distinct gray- 
ish tips to dorsal feathers. Bill deep coral-red; feet, horn-color. Wing, 3.55 ; tail, 4.00 ; culmen, . 80 ; bill from nostril, .52 ; depth at base, .67 ; tarsus, 1.00 ; middle toe, 65 .

Another adult of (No. 102,718) measures as follows: Wing, 3.55; tail, 4.00 ; culmen, .82 ; bill from nostril, .52 ; depth at base, .70 ; tarsus, 1.00 ; middle toe, .70 .

Adult ₹ (No. 102,719, Cozumel, January 23, 1885) : Capistrum blackish slate; rest of head raw-umber brown, becoming paler and more ochreous on sides of forehead and sides of neck, the latter, also the jugulum and lower parts generally, deep dull ochraceous, darker and more olivaceous along the sides; abdomen paler or buffy ochraceous, the anal region buffy whitish; lining of wing pure light vermilion. Longer crest-feathers dark brownish red, with broccoli-brown tips. Nape, back, scapulars, rump, and upper tail-coverts uniform broccolibrown; outer surface of wings dark dull red, the coverts and tertials edged with broccoli-brown. Tail dull dark red, the feathers edged with grayish brown; bill deep coral-red; feet horn-color. Wing, 3.45; tail, 4.05 ; culmen, .85; bill from nostril, .53; depth at base, .70 ; tarsus, 1.05 ; middle toe .72 .

Three other adult females measure as follows: Wing, 3.35-3.40 ; tail, $3.65-3.95$; culmen, .75-.80 ; bill from nostril, .50-.51; depth at base, $.65-.68$; tarsus, $1.00-1.03$; middle toe, .65-.75.

This race is closely related to $C$. cardinalis coccineus, Ridgw., from which it is separated chiefly on account of the more somber coloration of the female, that of Yucatan specimens, provisionally referred to coccineus, being much more tawny, with still blacker capistrum, and also with much smaller bills. The males of saturatus differ from those from the mainland in the darker and more purplish cast of the dorsal plum. age, the bill being also, as in the females, more robust.

It is doubtful whether the Yucatan birds of this species should be referred to the true coccineus, which was based upon specimens from the State of Vera Cruz. The writer has unfortunately been able to compare only males from the two regions. These agree minutely in coloration, but the Yucatan specimens are much smaller (smaller even than the Cozumel birds), and have relatively smaller bills. More material is necessary, however, to decide this question.

The authors of Biologia Centrali-Americana (Aves, I. p. 340) decline to accept the validity of $C$. cardinalis coccineus. They express their inability to "distinguish between specimens from Jalapa and others from Washington," and add that "as Sumichrast speaks of $C$. virginianus as a winter visitor to the State of Vera Cruz, the probability is that the birds of Eastern Mexico and Eastern States are of one species." The latter we do not deny, the name coccineus having been originally bestowed as a trinomial, and is retained as such, for the designation of a geographical race, whose claims, however, to recognition as a very strongly characterized form are clearly demonstrated by the specimens 
before us, and which, without exception, differ uniformly and decidedly in the two regions.

Laying aside the males, which though themselves readily distinguishable are much less obviously different than the females, we find, upon comparison of two adult females from Yucatan (Merida) with thirty from the Eastern United States, that while the former have a very rich tawny ochreous general coloration and black capistrum, all of the latter have the colors many shades paler and grayer and the capistrum gray instead of black. In fact, coccineus presents exactly the opposite extreme from igneus in regard to the color of the throat, the difference from true $C$. cardinalis being, if anything, even greater. Besides, coccineus is always a decidedly smaller bird, the arerage difference in length of wing and tail amounting at least to .25 of an inch.

An important factor in the case has been unfortunately misunderstood by Messrs. Salvin and Godman, which is that of all birds possessing the power of flight the birds of this genus are perhaps the most sedentary. Even at the very northern extreme of its range, C. cardinalis is a winter resident, enduring, without apparent discomfort, a cold of $-28^{\circ}$. And it is perhaps not too much to say that, except where transported accidentally, an individual of this species rarely, if ever, wanders so much as ten miles from the place of its birth!

\section{Family ICTERID $A$.}

[34. Dolichonyx oryzivorus (Linn.). Devis collection.]

+35. Icterus cucullatus Swains.

Two males, three females, the former apparently identical with Yucatan examples.

+36. Quiscalus macrourus Swains.

Two specimeus.

\section{Family TYRANNIDAE.}

†37. Tyrannus dominicensis (Gmel.).

One example.

- 38. Tyrannus melancholicus couchi (Baird).

Twelve specimens, not satisfactorily distinguishable from mainland examples, although they have purer ashy heads, grayer backs, and somewhat larger bills than most of the latter.

+ 39. Myiarchus platyrhynchus Ridgw.

Myiarchus platyrhynchus, RIDGw. Descr. New Sp. B. Cozumel, February 26, $1885,3$.

SP. CHAR.-Similar to M. barbirostris, Swains., of Jamaica, but upper parts much grayer, the pileum not so dark, and the upper tail-coverts, rectrices, and wing-feathers edged with darker rusty.

Adult 9 (No. 102,738, U. S. Nat. Mus., Cozumel): Above dull brown, 
without olire tinge, darker on pileum; upper tail-coverts and edges of rectrices, remiges, and greater wing-coverts rusty. Chin, throat, and jugulum pale ash-gray; rest of lower parts very pale sulphuryellow. Wing, 3.00 ; tail, 2.00 ; culmen, .85; bill from nostril, .50; width at base, .33 ; tarsus, .80 ; middle toe, .42 .

This bird is so elosely related to M. barbirostris, of Jamaica, that it should perhaps be considered merely a local race of it. However, the general coloration is very distinct on comparison; but to what extent this difference is due to action of alcohol on the feathers-the specimen having been preserved in spirits and afterwards skinned-is not known.

\section{Contopus schottii Lawr.?}

Four specimens, which uniformly differ from the type of $C$. schottii in decidedly grayer coloration above, with the pileum darker. They may represent a distinct form.

41. Empidonax gracilis Ridgw. (=E. minimus, Baird?)

Empidonax gracilis RidGw. Descr. New Sp. B. Cozumel, February 26, $1885,3$.

SP. CHAR.-Most like E. minimus, but the plumage much grayer, the lower parts witliout yellow tinge.

Adult \& (No. 102,737, U. S. Nat. Mus., Cozumel, January 22): Above ash-gray, more brownish, but still decidedly gray, on lower back, rump, and upper tail-coverts; a distinct orbital ring, two broad wing-bands, and broad edges to tertials grayish-white; sides of head light ashgray, fading to grayish white on throat; jugulum and sides of breast light brownish gray ; rest of lower parts white. Wing, 2.50; tail, 2.20; culmen, .55; bill from nostril, .25; width of bill at base, .23 ; tarsus, .60 ; middle toe, .30 .

This bird, of which a single specimen was collected and preserved in alcohol, so closely resembles the female of $E$. minimus, Baird, in dimensions as to cause a suspicion that it may be in reality a specimen of that species with all the yellow coloring abstracted from the plumage by the action of the alcohol in which it had been preserved before skinning. Still, the difference of coloration is much too great to allow of this hypothesis determining the question.

\section{Elainea martinica (Linn.)?}

Two specimens, one skinned from fresh bird the other from alcohol. The former I am unable to distinguish satisfactorily from some Dominiea specimens; but the latter is very different in appearance, all the yellowish tints having been extracted from the plumage by the alcohol, leaving the color dull brownish gray above and dull pale gray or grayish white beneath.

43. Elainea placens Scl.?

Four examples, two skinned from fresh birds and two from alcohol. The former agree very closely with Guatemala specimens of $E$. placens, 
but have the head rather more ashy and the whitish supereilium apparently more distinct. The latter, as in the case of alcoholic specimens of E. martinica and other species, are exceedingly different in appearance through extraction of the yellow coloring matter by the alcohol, leaving the plumage gray and jellowish white. More specimens, both from Cozumel and from the mainland, are required to determine the question as to whether they are identical or not.

\section{Family COTINGID A.}

† [44. Hadrostomus, species undetermined.]

Hadrostomus, sp.? Salv. Ibis, April, 1885, 191.

"A female or young male specimen of a species which I do not at present recognize. The bill is much larger than that of $H$. aglaice, of the adjoining coast. Nor does it agree with any specimens of $H$. niger that I have examined." (SALVIN, l. $c$.)

-45. Attila cozumelæ Ridgw.

Attila cozumela, Ridgw. Descr. New Sp. Birds Cozumel, February 26, 1885. Attila, sp.? Salvin, Ibis, April, 1885, 191.

SP. CHAR.-Most like A. citreopygia (Bonap.), but lower parts grayish white, the throat and jugulum rery indistinctly streaked with darker, the head much grayer, and the bill smaller.

Adult ồ (type, No. 102,767, U. S. Nat. Mus., Cozumel, January 29, 1885): Pileum brownish gray, streaked with black, and also streaked with white on forehead; dorsal region deep raw-umber brown, lighter and more olivaceous on the cervix, deeper and more rufescent posteriorly, especially on upper part of rump ; lower rump and upper tailcoverts ochraceous-yellow. Wings, in general, dusky, the lesser coverts and outer edges of tertials olive-brown; middle and greater coverts tipped with russet-brown, forming two tolerably distinct bands; primaries narrowly edged with grayish. Tail uniform raw.umber brown. Head, except on top, grayish white, streaked with grayish dusky, the auriculars tinged with yellowish olive. Chin and throat grayish white, indistinctly streaked with light gray; jugulum and breast grayish white or very pale gray, the darker streaks nearly obsolete, and the lateral portions, especially of jugulum, faintly tinged with olive yellow; abdomen immaculate white; sides and flanks deep ochraceous; crissum primrose-yellow; longer lower tail-coverts yellowish white; lining of wing pale buff-yellow. Bill horn-color, darker on upper mandible, but paler at tip; feet apparently plumbeous in life. Wing, 3.65; tail, 3.40 ; culmen, 1.20 ; bill from nostril, .75; tarsus, 1.00 ; middle toe, .65 .

Adult ㅇ (No. 102,765, Cozumel, January 28): Similar to the male, as described above, but pileum decidedly more brown, grayish streaks on side of head, throat, etc., much more indistinct, sides much paler ochra- 
ceous, and size decidedly smaller. Wing, 3.20 ; tail, 1.80 ; culmen, 1.10 ; bill from nostril, .68; tarsus, .97 ; middle toe, .60 .

Five specimens, compared with a series of sixteen from the mainland of Middle America (including specimens labeled A. citreopygia, A. sclateri, and A. cinnamomea), are all colored like those described above, showing the difference from the mainland representative (or, more properly, representatives, since there appear to be two and possibly three species) to be not only very obvious but also exceedingly constant.

\section{Family TROCHILID A.}

46. Trochilus colubris Linn.

One specimen, obtained January 22.

47. Lampornis prevosti thalassinus Ridgw.

Lampornis thalassinus, RIDGw. Descr. New Sp. B. Cozumel, February 26, $1885,3$.

Subsp. CHAR.-Most like L. prevosti (Less.), but upper parts less bronzy or more of a grass green, the black of the throat more extended, and the breast more bluish green.

Adult ô (type, No. 102,796, U. S. National Museum, Cozumel, January 24): Above uniform metallic grass-green, with golden reflections in certain lights; middle pair of rectrices metallic bottle-green or bronzegreen; rest of tail brilliant metallic violet-purple on a rich chestnut ground, the feathers bordered for terminal third, on both webs, with greenish black. Wing coverts metallic bronze-green, like the back; remiges uniform blackish dusk $y$, with a faint gloss of brownish purple in certain lights. Chin and throat uniform opaque relvety black, bordered along each side by brilliast metallic Paris green, this changing gradually on the jugulum to metallic sea-green, which gradually becomes less bluish toward the abdomen; sides and flanks bronzy green, like upper parts; exposed portion of lower tail-coverts dark chestnut, glossed with purple, and narrowly bordered terminally with dusky, the concealed portions of the feathers dull dusky greenish; anterior lower tail-coverts bright green. A line of white, downy feathers between flanks and rump. Bill and feet black. Wing, 2.60 ; tail, 1.55 ; culmen (to extreme base), 1.20, to frontal apices, 1.00 .

Immature of (No. 102,810, Cozumel, January 22): Above bronzy grassgreen, much duller than in the adult. Rectrices, except middle pair, with basal two-thirds chestnut, richly glossed with metallic violet-purple, the terminal third blue-black (glossed with bronze-green on edges), the tip white. Lower parts chiefly white, divided medially by an irregular line or stripe extending from the middle of the throat to the anal region, this opaque relveíy black anteriorly, the rest sea-green and dusky. Greeu of upper parts and white of lower surface separated, from rictus to sides of breast, by a somewhat broken stripe of deep cinnamon. Wing, 2.50 ; tail, 1.50 ; bill from frontal feathers, 1.00 . 
Adult o (No. 102,811, Cozumel, January 22): Similar to the young male, as described above, but without any of the cinnamon along sides of throat, ete., the black of the middle line of the throat extending anteriorly to the point of the chin, and white of cheeks reaching almost to the lower eye-lid. Wing, 2.60 ; tail, 1.60 ; bill from frontal feathers, 1.05 .

The examination of a larger series of this bird and L. prevosti than were compared when it was first described shows that it is not so distinct as at first seemed to be the ease. The characters given in the original diagnosis will, in the main, be found to hold good, and the form may be considered as a fairly well defined local race of $L$. prevosti.

48. Chlorostilbon forficatus Ridgw.

Chlorostilbon forficatus, RIDGw. Descr. New Sp. B. Cozumel, February 26, 1855,3. Chlorostilbon caniveti, Salv. Ibis, April, 1885, 191 (nec. Ornismya cuniveti, LEss.).

SP. CHAR.-Similar to C. caniveti (Less.), but tail much longer and more deeply forked. In o , length, 1.80-1.95 inches ; depth of fork, .901.15 inches. In $q$, length, 1.50 ; depth of fork, .42.

Adult ô (type, No. 102,812, U. S. National Museum, Cozumel, January 23,1885): Above brilliant golden grass-green, more luminous on forehead and crown; tail blue-black, the six middle feathers tipped with brownish slate; remiges dull purplish dusky. Lower parts luminous Paris green, the chin, throat, and jugulum more emerald. Bill dull brown on basal third (in dried skin), the terminal two-thirds (approximately) black; feet brownish black. Wing, 1.90 ; tail, 1.90 , forked for 1.15 , the lateral feather .42 longer than the next; bill from frontal feathers, .55.

Adult $\subsetneq$ (No. 102,821, U. S. Nat. Mus., Cozumel, January 22, 1885): Above uniform metallic grass-green, including four median rectrices, which, however, are not so bright as the back and rump; lateral rectrix with tip for about .20 of an inch, and a band about .25 wide, commencing at 1.70 from the tip, pale brownish gray, the basal and subterminal spaces blue-black; second rectrix with basal half metallic green, the remaining half blue-black, tipped with pale brownish gray, the green interrupted on outer web by a spot of pale dull gray; third rectrix without any gray, even at tip, the terminal third blue black, thebasal two thirds uniform green. Auriculars grayish white, bordered anteriorly and inferiorly by a broad band of dull greenish dusky, ex. tending obliquely from the eye across the cheeks, and connecting with the green on the side of the neck. Lower parts, including lores and malar region, uniform grayish white, the sides, however, chiefly metallic green, like the back. Bill blackish, the basal two thirds of the lower mandible light brownish. Wing, 1.95 ; tail, 1.45 , forked for 40 of an inch; bill from frontal feathers, .62.

Thirteen specimens (nine males and four females) agree very closely among themselves in the characters presented above. 
Not having a specimen of $C$. auriceps, Gould, for comparison, I am unable to state whether the Cozumel species is more nearly related to it or to (J. caniveti (Less.). The three species (the males, at least) appear to differ only in proportions. There is certainly no appreciable difference in color between males of $C$. forficatus and those of $C$. caniveti; and Mr. D. G. Elliot says (Ibis, 1875, p. 169) that " in size and general color of plumage" $C$. auriceps and $C$. caniveti "are as nearly alike as can be; and specimens of caniveti possess as brilliantly colored crowns as any that can be found in auriceps, thus reducing the distinctive character of its name to nil." $\quad$. auriceps, according to Mr. Elliot (l. c.), "is remarkable for its narrow and greatly lengthened outer rectrices, which extend beyond those next to them .55 of an inch," and must therefore be distinct from $C$. forficatus.

\section{Family PICID $A$ E.}

[49. Dryobates scalaris (Wagl.). Devis collection.] Picus scalaris SALvin. Ibis, April, 1885, 191.

50. Centurus dubius leei Ridgw.

Centurus leei, Ridgw. Deser. New Sp. B. Cozumel, February 26, 1885, 3. Centurus aubius, SAlv. Ibis, April, 1885, 192 (nec Picus dubius Cabot).

Sp. CHAR.-Similar to C. aubius (Cabot), but lower parts darker, and lower rump and upper tail coverts usually barred with black.

Adult ơ (type, No. 102,777, U. S. Nat. Mus., Cozumel, January 28): Frontlet dull rermilion-red; crown, occiput, and cervix crimson, becoming gradually lighter, or more of a vermilion-red, on the lower part of the cervix, the crimson of the crown separated from the lighter red of the frontlet by a narrow band of pale buffy gray. Upper parts black, thickly marked with narrow undulated bars of soiled white, these bars about .05 of an inch wide and .08-.10 of an inch apart on the back, but much farther apart on the wings (.12-.15 of an inch). Primary-coverts immaculate black; primaries black, with a few irregular spots of white near the base, the 6 th to 10 th quills, inclusive, with narrow terminal margins of white. Lower part of rump and upper tail-coverts soiled white, everywhere narrowly barred with black, the bars about .05 of an inch wide and .15 of an inch apart. Tail uniform black, the outer feather (on each side) with two irregular narrow bars of brownish white across both webs near the tip, the exterior margin indented with white for nearly the terminal half. Sides of head and neck, and lower parts generally, plain smoky drab, lighter toward the chin, but especially before and above the eye, more olivaceous on the sides; abdomen bright vermilion-red; femorals, anal region, and lower tail-coverts barred with dusky and brownish white, the latter somewhat tinged with red. Bill black; feet dusky (olive-greenish in life?). Wing, 5.15; tail, 3.90.

Adult $\checkmark$ (No. 102,781, U. S. Nat. Mus., Cozumel, January 28): Similar to the male, as described above, but red of the head confined to the frontlet and cervix, the occiput and crown being smoky gray or light 
drab, becoming gradually paler anteriorly. Wing, 5.10; tail, 3.65 ; culmen, 1.35 .

Thirteen skins (five male and eight female), besides four alcoholic specimens, agree in the possession, to a greater or less extent, of the characters which separate this bird from its mainland representative (C. dubius), of which about a dozen specimens have been compared with the Cozumel series. In C.dubius the upper tail coverts and lower part of the rump are invariably immaculate white, and the lower parts a rather light olive-gray. In C. leei, three of the five males and five out of eight females have both the lower rump and the upper tail-coverts decidedly varied (usually barred) with black, while the exceptional specimens have only the longer upper tail-coverts immaculate, and these usually with black shafts or other concealed markings. The lower parts are in every instance decidedly darker than in the mainland bird, the red of rhe abdomen also being much more intense.

+51. Centurus rubriventris pygmæus, subsp. nov.

Centurus rubriventris Salvin, Ibis, April, 1885, 192 (nec Swains.).

SUBSP. CHAR.-Differing from true C. rubriventris in decidedly smaller size, narrower white bars of the upper parts, and grayer coloration of the lower parts.

Adult ô (type, No. 102,791, U. S. Nat. Mus., Cozumel, January 28): Frontlet cadmium-yellow, paler and duller on the nasal tufts ; forehead smoky white, passing gradually into light drab on the lores and sides of the pileum, the same color extending uniformly over the entire lat. eral portion of the head and neck, the chin, throat, and jugulum, and continued in a deeper, more olivaceous shade, over the breast and sides. Crown with an ovoid patch of bright crimson, about .70 of an inch long by .40 wide; cervix bright vermilion-red, tinged with orange at the lower edge, the two red areas brokenly confluent on the occiput. Upper parts black, the back and scapulars very narrowly barred with dingy white, the wings with broader, more distant bars of pure white; primary-coverts uniform black; primaries spotted with white near outer webs, the longer quills narrowly margined with white beyond their sinuations, the shorter (innermost) quills narrowly tipped, on outer webs, with white. Upper tail-coverts and lower part of rump immaculate white. Tail uniform black, the intermediæ with much of the basal half, of both webs, white, though this is mostly concealed by the upper coverts; outer pair of rectrices with terminal half barred, about half way across outer web, with white. Middle of abdomen bright vermilion-red; femoral region, anal region, and lower tail-coverts olivaceous-white, barred with blackish, the markings more sagittate on lower tail-corerts. Bill wholly black; feet dusky (olivaçeous or plum. beous in life?). Wing, 4.00 ; tail, 3.00 ; culmen (exposed portiou), .80; tiirsus, .i0.

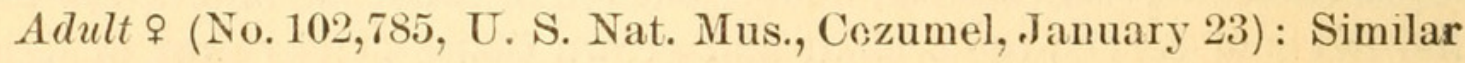


Vol. VIII, Vo. :

to the male, but red of head confined to the cervix, the whole crown and occiput being smoky drab, more olivaceous on the nape. Wing, 3.90 ; tail, 2.80 ; culmen (exposed portion), .75; tarsus, .70.

Four males and the same number of females of this well-marked race of a very distinct little species are in the collection. In all of them the frontlet is bright cadmium-yellow (paler and duller in some females), in very striking contrast to the red of the crown or cervix. In the males, the red of the crown is very nearly separated from that of the cervix, by the encroachment of the olive-gray on the sides of the occiput. In all of the males and three of females, the middle pair of the rectrices are marked with white on the basal portion of both webs, the white being in all cases more extended on the inner web. In a single female (No. 102,789), the white is entirely confined to the inner web, and is reduced to a mark so small as to be almost concealed by the coverts. The length of the wing is exactly 4 inches in the males, and varies only from 3.85 to 3.90 in the females.

Two examples of true C. rubriventris, from Yucatan, measure as follows:

\begin{tabular}{|c|c|c|c|c|c|c|c|}
\hline Museum and number. & 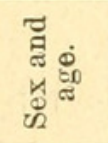 & Locality. & $\stackrel{\dot{b}}{\Xi}$ & $\begin{array}{l}\text { नีं } \\
\text { Еี }\end{array}$ & 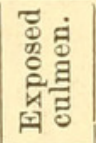 & $\begin{array}{l}\dot{\Phi} \\
\vec{\Xi} \\
\stackrel{\Xi}{\Xi} \\
\stackrel{H}{-1}\end{array}$ & Collector. \\
\hline $\begin{array}{l}36803, \text { U. S. Nat. Mus . } \\
\text { Mus. G. N. L ... }\end{array}$ & $\begin{array}{l}\text { of ad. } \\
\text { o ad. } \\
0 \\
0\end{array}$ & $\begin{array}{l}\text { Merida, Yucatan ...... } \\
\text { (Unknown) } \ldots . . . . . . . . \\
\end{array}$ & $\begin{array}{l}4.30 \\
4.25 \\
4.30\end{array}$ & $\begin{array}{l}2.80 \\
2.80 \\
3.00\end{array}$ & $\begin{array}{r}.85 \\
.70 \\
\cdots \cdots\end{array}$ & $\begin{array}{r}.70 \\
.65 \\
\cdots \cdots\end{array}$ & $\begin{array}{l}\text { Dr. A. Schott. } \\
\text { G. F. Gaumer. } \\
\text { (Swainson's type.) }\end{array}$ \\
\hline
\end{tabular}

\section{Family CUCULID E.}

52. Crotophaga ani Linn.

Two specimens. The occurrence of this West Indian species to the exclusion of $C$. sulcirostris, Swains., which is so numerous in Yucatan, is somewhat remarkable.

\section{Family PSITTACIDEE.}

\section{Chrysotis xantholora Gray.}

Three specimens-two adults and one young. The latter is colored as follows:

Young (No. 100,119, U. S. Nat. Mus., Cozumel I., Yucatar, January): In general coloration like the adult, but differing as follows: Forehead and crown blue, instead of white; the feathers with a narrow terminal margin of black. The red of the orbital region is replaced by green, though indicated by a few scattered red feathers, belonging to the new moult. The black subauricular spot is wanting, as is also the red border of the fore-wing (campterium). The three outer primary coverts are

Proc. Nat. Mus. $85-37$ 
green (all being intense poppy-red in the adult).* The larger wingcoverts and tertials margined terminally with light yellowish green.

\section{Family FALCONID无.}

54. Buteo brachyurus Vieill.

A young male, which may be described as follows:

Young ô (No. 102,855, U. S. Nat. Mus., Cozumel I., Yucatan, January 24, 1885): Upper parts nearly uniform dull dusky brown, the head rather darker, or blackish brown, much broken by white streaking, the whole basal portion of the feathers being white; feathers of nape and upper part of back also white beneath the surface, the division of the white and brown directly transverse; scapulars with decidedly but indistinctly lighter brown margins, these edgings inclining on some feathers to dull ochraceous. Outer surface of primaries uniform brownish black. Tail dull grayish brown, with indications, most distinct next the shaft, of about seven narrow dusky bands, the last of which is much broader than the rest. (These bands scarcely show at all when the tail is closed, except on the middle rectrices.) Tip of tail narrowly and indistinctly pale brownish gray. Forehead and anterior portion of lores immaculate white; sides of head, including superciliary and supra-auricular regions, suborbital region and auriculars, streaked with white and dusky, in nearly equal proportion; sides of neck similarly but more broadly streaked, and slightly mixed on the lower portion with rusty ochraceous. Entire lower parts, from chin to crissum, including the whole lining of the wing, axillars, and greater extent of under surface of remiges (in closed wing), immaculate white, the upper portion of outer side and whole of inner side of tibiæ deep creamy buff, or light ochraceous. Tail slightly emarginate when closed, truncate when spread; third and fourth quills longest, the others succeeding in the following order: 5th, $2 \mathrm{~d}, 6 \mathrm{th}, 7 \mathrm{th}, 8 \mathrm{th}, 1 \mathrm{st}, 9 \mathrm{th}, 10 \mathrm{th}$, the 1 st and 8 th being very nearly equal, however. Only three outer primaries with inner webs distinctly emarginated, but fourth showing an appreciable sinuation. Wing, 10.50 ; tail, 6.00 ; culmen, .68; tarsus, 2.30 (unfeathered portion 1.35); middle toe, 1.40 .

+ 55. Rupornis magnirostris gracilis Ridgw.

Asturina ruficauda Salv. Ibis, April, 1885, 193 (nec Scl. \& SAlv., P. Z. S. $1869,133)$.

Rupornis gracilis RIDGw. Proc. U. S. Nat. Mus. VIII, May 20, 1885, 94.

SUBSP. CHAR.- Similar to $R$. magnirostris griseocauda, RIDGW., $\dagger$ but

* Only the longest feather of the alula is present. In the adult the shortest (last) is red, like the primary coverts, and this feather is probably green in the young.

† Buteo (Rupornis) magnirostris, c. var. griseocauda, RIDGw., Proc. Boston Soc. N. H., May 21, 1874, 88.-Rupornis magnirostris (Gmel.), is a name which in all probability should cover a variable species, the range of which extends from southern Mexico to Bolivia and the Argentine Republic, and to the several more or less strongly characterized geographical races to which different specific names have been given. These 
decidedly smaller, and with the thighs and under wing-coverts nearly or quite immaculate, instead of distinctly barred and spotted, respectively. Wing, 8.00-8.80 (average of the specimens, 8.44); tail, 6.00-6.30 (average, 6.13); culmen, .60-.72 (average, .67); tarsus, 2.20-2.40 (average, 2.33 ); middle toe, 1.05-1.20 (average, 1.17).

Male, nearly adult (type, No. 102,852, Cozumel, January 27, 1885): Upper parts nearly uniform grayish brown, the feathers with dusky shafts, and those of the dorsal region and wings with very narrow and rather indistinct paler margins, especially terminally; longer upper tail-coverts buff, or pale ochraceous, marked with sharply defined transverse, nearly reniform, spots of umber brown. Tail deep brownish gray, erossed by 4 bands of black, averaging about .50 of an inch wide, or nearly as wide as the brownish gray interspaces; the width gradually decreasing, however, from the last, or subterminal one, which is succeeded by a narrower

races are (1) the true magnirostris, from South America north of the Amazon ; (2) Asturina nattereri, ScL. \& SALV., from Brazil and eastern Peru ; (3) Asturina ruficauda, Scl. \& SAlv., from Central America (Isthmus of Panama to Nicaragua); (4) Rupornis magnirostris griseocauda, Ridgw., from southern Mexico and Guatemala, and (5) R. magnirostris gracilis, an insular form from the Island of Cozumel. To these it may hereafter prove necessary to add (6) Asturina pucherani, Verr., from the Argentine Republic, and (7) A. saturata, Scl. \& Salv., from Bolivia. Intergradation between two of the above named forms has been proven in two instances, viz., between magnirostris and nattereri and between ruficauda and griseocauda, respectively; and in the case of the others, the relationship is so close that intergradation may safely be assumed. A. saturata apparently connects nattereri with pucherani, or at least has resemblances to both. Some authors have refused to recognize the validity of the form which I have named griseocauda, on the ground that intermediate specimens connect it with ruficauda; but in so ruling they utterly ignore the very distinction between species and geographical races, $i$. e., the fact of intergradation in the case of the latter. Giving this distinction due consideration, it is found that griseocauda is just as well marked a race as any of the forms which have usually been ranked good species, but the circumstance that ruficauda and griseocauda are better represented, both numerically and as to locality, in collections than are the others, and that intermediate specimens are consequently more numerous, has rendered its distinctness less apparent.

The National Museum collection contains 23 adult specimens of ruficauda and griseocauda together; and the way in which the two forms intergrade, as shown by this series, is as follows:

Panama (1 specimen).-Tail-bands rufous.

Chiriqui (1 specimen).-Tail-bands rufous.

Costa Rica (8 specimens).-Tail-bands rufous in 4, chiefly rufous in 3, and gray mixed with rufous in 1 .

Nicaragua (5 specimens).-Tail-bands with rufous predominating in 1, with gray predominating in 4 .

Guatemala (1 specimen). -Tail-bands gray, but much tinged with rufous, especially on lateral feathers.

Yucatan (5 specimens).-Tail-bands gray in all; in 3 of them, the basal portion of the outer web of lateral rectrices mottled with pale ochraceous, and in 2 others the same portions tinged with rufous.

Tehuantepec (1 specimen).- - Tail-bands gray, the outer web of lateral rectrices tinged with rufous at base.

Vera Cruz (1 specimen, from Mirador).-Tail-bands gray, the basal portion of the rectrices (except middle pair) tinged with rufous. 
band of brownish gray, gradually passing into dull whitish at the terminal margin; extreme base of the tail (concealed by the covert ), buffy white, this becoming ochraceous-buff on the basal portion of the two lateral rectrices, on which this color occupies nearly the basal third. Primaries brownish dusky, all except the three ontermost with a greater or less number of quadrate ferruginous spots, disposed in transcerse bands. Whole side of head uniform grayish brown, somewhat paler than the pileum ; extreme anterior portion of the forehead dull whitish. Chin and upper part of throat dull white, marked with narrow cuneate streaks of grayish brown; lower part of throat light buff, marked with similar, but larger streaks; jugulum and upper part of breast with grayish brown prevailing, but the feathers much spotted or otherwise marked on the edges with buffy white, forming broken or irregular longitudinal stripes; rest of lower parts buffy white, the entire sides, lower part of breast, and upper part of abdomen marked with sharply defined transverse spots, or broad, somewhat reniform, bars, of umber brown. Tibiæ deep ochraceous-buff, the upper half (or more) of the outer side marked with narrow bars of brown; crissum deep creamy buff, passing into buffy white on lower tail-coverts; lining of the wing light buff, sparsely marked with a few small spots and streaks of brown. Bill dusky, clouded with light horn-yellowish; feet apparently deep yellow in life. Wing, 8.20; tail, 6.00; culmen, .67; tarsus, 2.35 ; middde toe, 1.08.

Female, nearly adult (No. 182,849, U. S. Nat. Mus., Cozumel, January 27): Almost exactly like the male, as described above. Wing, 8.70; tail, 6.20 ; culmen, .70; tarsus, 2.35 ; middle toe, 1.15 .

Young ô (No. 102,853, U. S. Nat. Mus., Cozumel, January 27) : Upper parts much as in the adult, but pileum streaked with buffy white, the brown spots on upper tail coverts less transverse, or more cordate, and the brown tail-bands narrower and less grayish, a fifth rather indistinct dusky band showing beyond the tips of the upper tail-coverts. Primaries without ferruginous markings, but spotted, in transverse bands, with grayish brown instead. Lower parts pale buff, approaching white anteriorly, with no transverse markings, but the throat, jugulum, breast, and sides marked with longitudinal guttate and lanceolate stripes and streaks of deep brown, these streaks largest and broadest on the sides, smallest on the throat. Tibiæ ochraceous-buff, marked on the outer side with a few small cordate and triangular spots of grayish brown. Wing, 8.00 ; tail, 6.00 ; culmen, .60 ; tarsus, 2.35 ; middle toe, 1.12 .

Young 오 (No. 102,848, U. S. Nat. Mus., Cozumel, January 23): Essentially like the young male, as described above, but stripes on breast, etc., broader and rather paler brown, the markings on sides and flanks in the form of spots, arranged in chain-like series. Wing, 8.35; tail, 6.20 ; culmen, .70; tarsus, 2.40 ; middle toe, 1.10 . 
56. Urubitinga anthracina Nitzsch.

One specimen, a fine adult, shot while feeding on a Curassow (Crax globicera?).

\section{Family COLUMBID $A$.}

[57. Columba leucocephala Linn. Devis collection.]

[58. Engyptila jamaicensis (Linn.)? Devis collection.]

59. Columbigallina passerina (Linn.).

Two specimens.

+60. Columbigallina rufipennis (Bp.).

Two specimens.

\section{Family CRACIDAE.}

61. Crax globicera Linn.?

Only a few remiges of a female specimen, upon which a Urubitinga anthracina had been feeding. These feathers are different from the corresponding ones of any example of C. globicera in the National Museum collection, but the latter species itself varies so much in coloring that nothing can be decided as to the status of the Cozumel bird without a complete specimen, or perhaps a series of specimens.

Fämily ARDEID无.

62. Garzetta candidissima (Gmel.).

A fine adult, in full nuptial plumage.

Family CHARADRIID $Æ$.

63. Oxyechus vociferus (Linn.).

One specimen.

Family SCOLOPACID Æ.

64. Artitis macularius (Linn.).

One specimen.

In order to show the complicated relationships of the Cozumel bird fauna, the following list is presented, including all the species known to have been found there to date, together with their geographical distribution: 


\section{Fam. SYLVIID \&.}

1. Polioptila cœrulea (Linn.)

Fam. Mrmid 五.

2. Harporhynchus guttatus, Ridgw

3. Mimus gilvus gracilis (Cab.)

5. Melanoptila glabrirostris, Scl ......... Fam. Troglodytide.

6. Troglodytes beani, Ridgw Fam. MNiotiltidæ.

7. Mniotilta varia (Linn.)

8. Compsothlypis americana (Linn.)

9. Dendroica petechia rufivertex, Ridgw

10. Dendroica virens (Gmel.)

11. Dendroica cerulescens (Linn.)

12. Dendroica maculosa (Gmel.)

13. Dendroica dominica albilora, Baird

14. Dendroica palmarum (Gmel.)

15. Dendroica discolor (Vieill.) ..........................

16. Seiurus noveboracensis notabilis, Ridgw

17. Seinrus aurocapillus (Linn.)

18. Geothlypis trichas occidentalis, Brewst

19. Sylvania mitrata (Gmel.)

20. Setophaga ruticilla (Linn.)

Fam. Cerebide.

21. Certhiola caboti, Baird...

Fam. VIREONID五.

22. Vireo cinereus, Ridgw . .

23. Vireo flavifrons, Vieill

24. Vireo noveboracensis (Gmel.)

25. Vireo bairdii, Ridgw

26. Cyclorhis insularis, Ridgw Fam. TANAGRID五.

27. Spindalis benedicti, Ridgw

28. Piranga roseigularis, Cabot

\section{Fam. Fringillid 五.}

29. Ammodramus savannarum passerinus (Wils.)

30. Passerina cyanea (Linn.)

31. Passerina ciris (Linn.)

32. Euetheia olivacea intermedia, Ridgw

33. Cardinalis cardinalis saturatus, Ridgw. Fam. ICTERIDÆ.

34. Dolichonyx oryzivorus (Linn.).

35. Icterus cucullatus, Swains

36. Quiscalus macrourus, Swain

\section{Fam. Tyrannid 2 .}

37. Tyrannus dominicensis (Gmel.)

38. Tyrannus melancholicus conchi (Baird)

39. Myiarchus platyrhynchus, Ridgw ....

40. Contopus schottii, Lawr. ?...

41. Empidonax gracilis, Ridgw

42. Elainea martinica (Linn.) ? .............

43. Elainea placens, Scl. ?

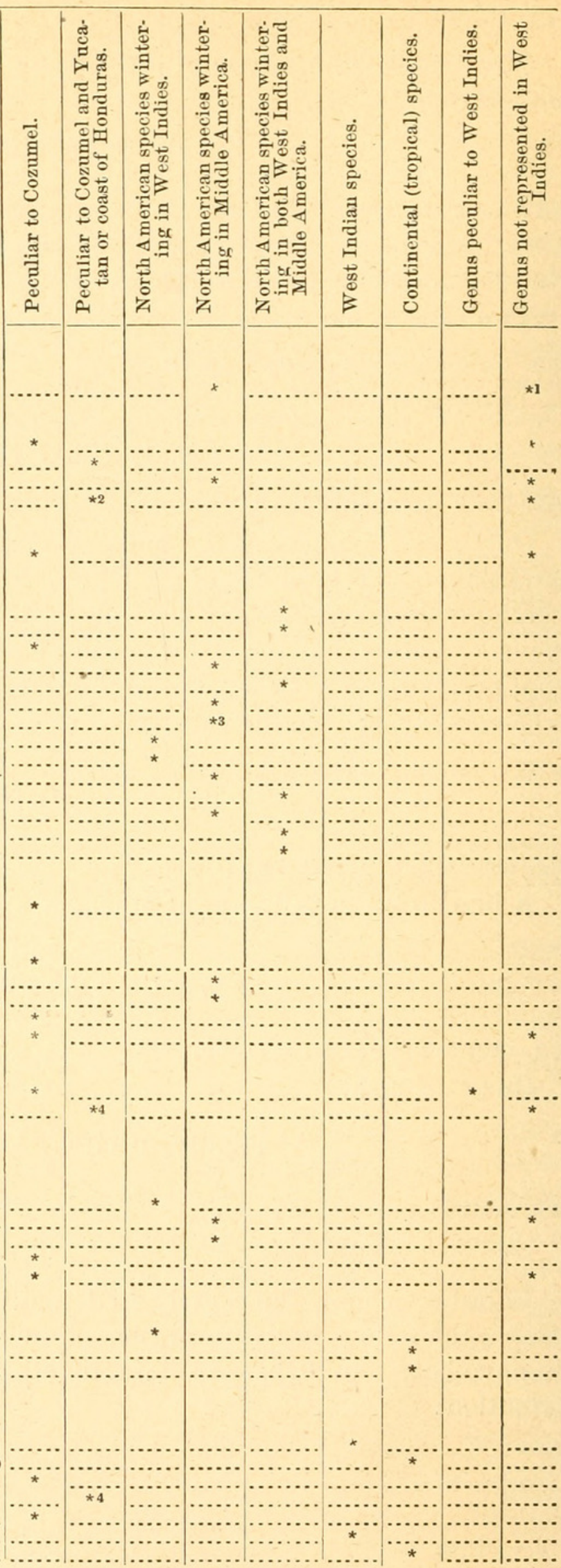

${ }^{1}$ A peculiar species in Cuba ( $P$. lembeyi).

2 Not yet found in Yucatan.

3 The typical form resident in West Indies.

4 Known only from Cozumel and Yucatan. 


\section{Fam. Contingider.}

44. Hadrostomus (undetermined)

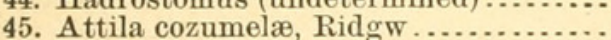

Fam. Trochilid 五.

46. Trochilus colubris, Linn ....................

47. Lampornis prevosti thalassinus, Ridgw 48. Chlorostilbon forificatus, Ridgw.......

Fam. Picide.

49. Dryobates scalaris (Wagl.) .

50. Centurus dubius leei, Ridgw

51. Centurus rubriventris pygmæus, Ridgw

Fam. Cuculide.

52. Crotophaga ani, Linn.

Fam. Psittacid 瓜.

53. Chrysotis xantholora, Gray.

Fam. Falconide.

54. Buteo brachyurus, Vieill .................
55. Rupornis magnirostris gracilis, Ridgw.

56. Urubitinga anthracina, Nitzsch ...

Fam. Columbide.

57. Columba leucocephala, Linn.

58. Engyptila jamaicensis (Linn.) ? ${ }^{2}$.

59. Columbigallina passerina (Linn.) .

60. Columbigallina rufipennis (Bonap.).

Fam. Cracide.

61. Crax globicera, Linn.?

Fam. ARDEID .

62. Garzetta candiảissima (Gmel.)

Fam. Charadriide.

63. Oxyechus vociferus (Linn.)

Fam. SCOLOPACIDA.

64. Actitis macularius (Linn.)

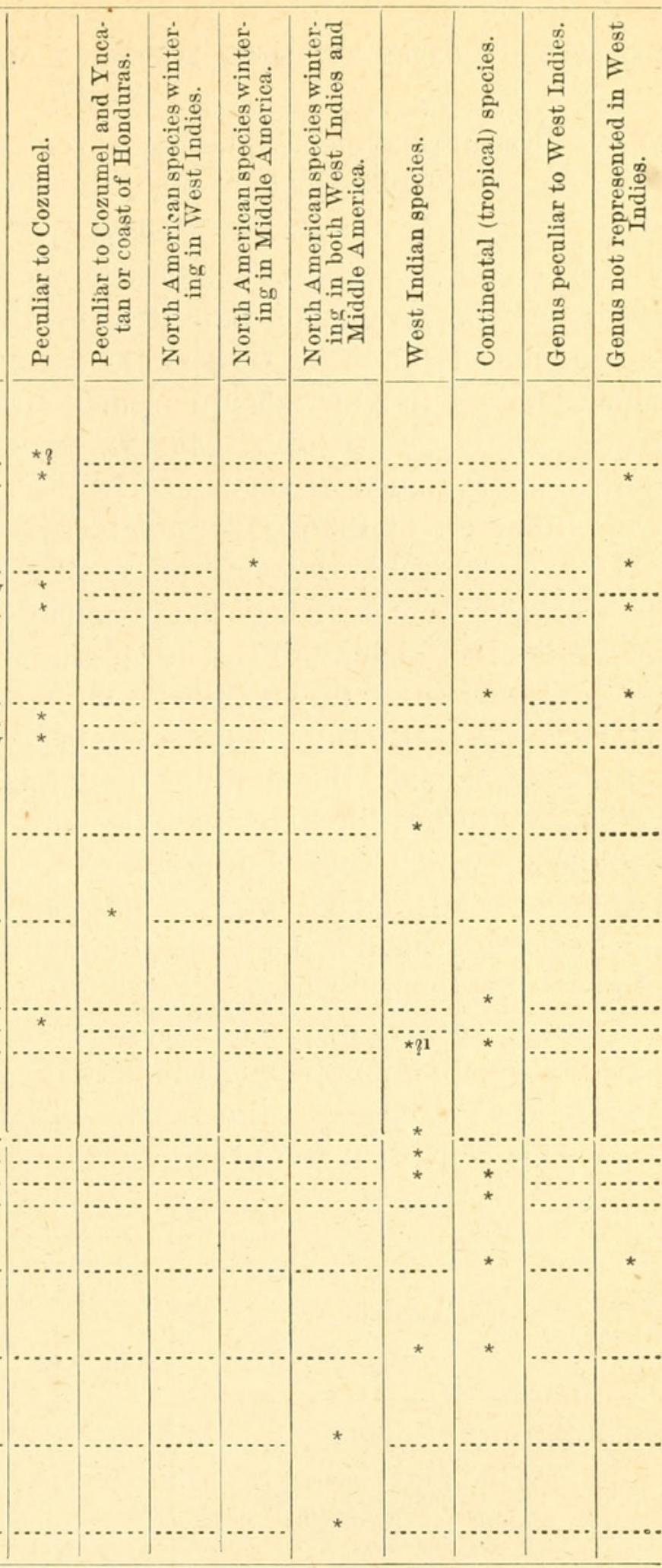

1 The West Indian bird possibly distinet, as U. gundlachi (Cab.).

${ }^{2}=E$. gaumeri, Lawr., but apparently not sufliciently distinct from the Jamaican bird.

\section{RECAPITULATION.}

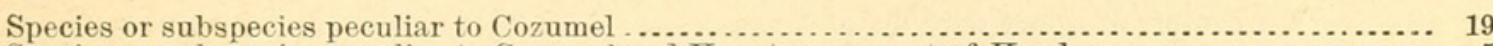

Species or subspecies peculiar to Cozumel and Yucatan or coast of Honduras ...................... 5

North American species wintering in West Indies . . . . . . . . . .

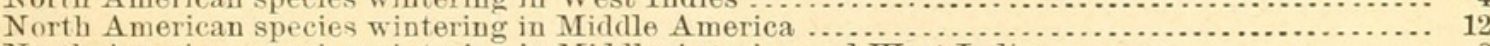

North A merican species wintering in Middle America and West Indies . . ...................... 8

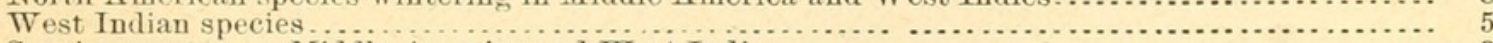

Species common to Middle A merica and West Indies . . . . . . .

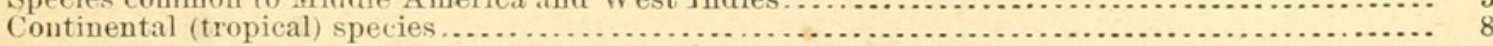

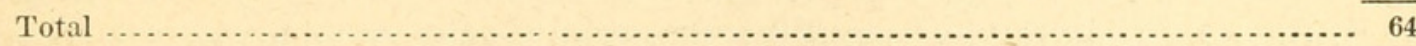

Genera peculiar to West Indies ..................

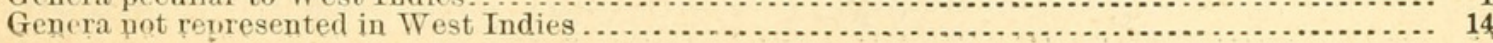



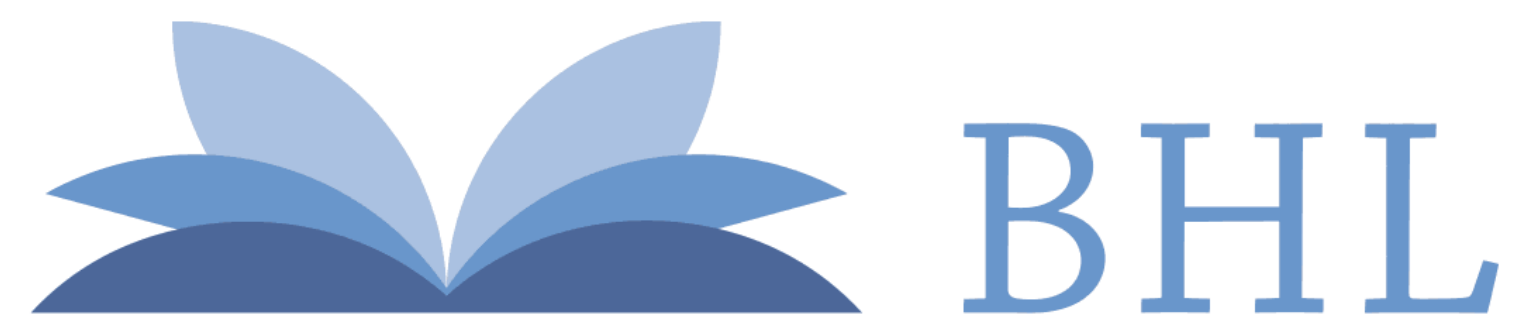

\section{Biodiversity Heritage Library}

Ridgway, Robert. 1885. "Catalogue of a collection of birds made on the Island of Cozumel, Yucatan, by the naturalists of the U. S. Fish Commission steamer Albatross, Capt. Z.L. Tanner, Commander." Proceedings of the United States National Museum 8(539), 560-583. https://doi.org/10.5479/si.00963801.539.560

View This Item Online: $\underline{\text { https://www.biodiversitylibrary.org/item/52770 }}$

DOI: https://doi.org/10.5479/si.00963801.539.560

Permalink: https://www.biodiversitylibrary.org/partpdf/51014

\section{Holding Institution}

Smithsonian Libraries

\section{Sponsored by}

Smithsonian

\section{Copyright \& Reuse}

Copyright Status: Public domain. The BHL considers that this work is no longer under copyright protection.

This document was created from content at the Biodiversity Heritage Library, the world's largest open access digital library for biodiversity literature and archives. Visit BHL at https://www.biodiversitylibrary.org. 